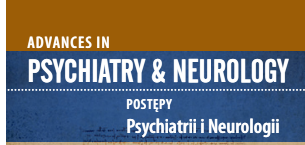

Correspondence to/

Adres do korespondencji:

Dr Aleksandra Wierzbicka Zakład Neurofizjologii Klinicznej, Instytut Psychiatrii i Neurologii

ul. Sobieskiego 9

02-957 Warszawa

phone: +48224582634

fax: +48224582817

e-mail: wierzbic@ipin.edu.pl

Submitted/Otrzymano: 28.05.2017

Accepted/Przyjęto do druku: 10.07.2017

\section{REM BEHAVIOUR SLEEP DISORDER - CASE STUDY}

\section{ZABURZENIA ZACHOWANIA W CZASIE SNU REM - OPIS PRZYPADKU}

\author{
Aleksandra Wierzbicka', Katarzyna Szaulińska², \\ Ewa Poradowska², Wojciech Jernajczyk? , \\ Adam Wichniak ${ }^{1,2}$
}

\author{
'Department of Clinical Neurophysiology, Institute of Psychiatry and Neurology, \\ Warsaw, Poland \\ ${ }^{23^{\text {rd }}}$ Psychiatric Clinic, Institute of Psychiatry and Neurology, Warsaw, Poland \\ 'Zakład Neurofizjologii Klinicznej, Instytut Psychiatrii i Neurologii, Warszawa, Polska \\ 2III Klinika Psychiatryczna, Instytut Psychiatrii i Neurologii, Warszawa, Polska
}

\begin{abstract}
Purpose: REM behaviour sleep disorder (RBD) is a parasomnia and involves sudden movements and/or vocalizations that reflect the dream content. This disorder is a common symptom of neurodegenerative diseases or their prodromal symptom. Until recently, clonazepam was the most commonly used drug to relieve symptoms of RBD. The aim of the article is to describe successful RBD treatment with melatonin.

Case description: A case of a 56-year-old man with a history of symptoms characteristic for RBD was presented. The initial diagnosis was confirmed by video-polysomnography in the course of which clinical episodes and periods of muscle atonia during REM sleep were recorded. The cause of RBD was not identified, an idiopathic form of the disorder was diagnosed. Melatonin was used for treatment in the target dose of $5 \mathrm{mg} /$ day with a satisfactory result. Due to an increased risk of a neurodegenerative disease, the patient remained under care of a neurologist.

Comment: Due to more frequently reported effectiveness of melatonin in RBD treatment with a low risk of adverse reactions and interactions with other drugs, it is worth considering its use before the decision to administer clonazepam, especially in the elderly.

Key words: REM behaviour sleep disorders, melatonin, polysomnography.
\end{abstract}

\title{
Streszczenie
}

Cel: Zaburzenia zachowania w czasie snu REM (RBD) należą do parasomnii i mają charakter gwałtownych ruchów i/lub wokalizacji, odzwierciedlających treść marzeń sennych. Zaburzenie to jest częstym objawem chorób neurozwyrodnieniowych lub ich objawem prodromalnym. Najczęściej stosowanym lekiem łagodzącym RBD był do niedawna klonazepam. Celem artykułu jest opis skutecznego leczenia RBD melatoniną.

Opis przypadku: Przedstawiono przypadek 56-letniego mężczyzny z wywiadem objawów charakterystycznych dla RBD. Wstępne rozpoznanie potwierdzono badaniem polisomnograficznym $\mathrm{z}$ rejestracją wideo, $\mathrm{w}$ którym zarejestrowano epizody kliniczne oraz okresy atonii mięśniowej podczas snu REM. Nie ustalono przyczyny RBD, rozpoznano postać idiopatyczną zaburzenia. Zastosowano leczenie melatoniną w dawce docelowej $5 \mathrm{mg}$ /dobę z zadowalającym efektem. W związku ze zwiększonym ryzykiem zachorowania na chorobę neurozwyrodnieniową pacjent pozostał pod opieką neurologa.

Komentarz: Ze względu na coraz częściej opisywaną skuteczność melatoniny w leczeniu RBD, przy niskim ryzyku działań niepożądanych i interakcji z innymi lekami, warto rozważać jej zastosowanie przed podjęciem decyzji o podawaniu klonazepamu, zwłaszcza u osób starszych.

Słowa kluczowe: zaburzenia zachowania w czasie snu REM, melatonina, polisomnografia. 


\section{PURPOSE}

Parasomnias are movement disorders occurring during sleep at night or at sleep-wake transitions. As far as the stage of sleep at which they occur is concerned, parasomnias may be divided into rapid eye movement (REM) sleep-related parasomnias and non-rapid eye movement (NREM) sleep-related parasomnias [1]. Correct identification of the type of parasomnia implies the introduction of appropriate treatment. In the case of REM sleep-related parasomnias, the reason why patients seek medical advice are often REM sleep behaviour sleep disorders (RBD). These disorders are characterised by complex, often sudden body movements and/or vocalizations closely related to the dream content [2]. Dreams causing RBD are often very vivid, full of negative emotions, with content associated with the escape, chase, fight, and other threats, which is manifested by sudden limb movements, such as punching, pinching, scratching and kicking. Such episodes may result in injury to patient or bed partner. Most frequently these include injuries or broken limb bones, but also more serious head injuries caused by falling out of bed $[3,4]$. RBD may also manifest itself in loud vocalizations, such as screaming, single words or complex sentences, which occur separately or accompany the movements. The feature that causes embarrassment in patients is shouting vulgar words during RBD episodes, especially in people who do not use vulgar language at all in their everyday life. RBD symptoms may initially go unnoticed due to their lower intensity. Motor symptoms may be limited to finger and hand movements, and reflect dreams that are for example associated with frequently performed work (playing the piano, crocheting). As RBD is related to REM sleep, this disorder occurs mainly in the second half of the night, when REM sleep periods are more frequent and longer. The number of RBD episodes varies from a few per year to several each night.

The most commonly used drug to relieve RBD symptoms is clonazepam. However, it is associated with a number of adverse reactions, especially in older patients. Beneficial effects of melatonin in the treatment of RBD were for the first time described in 1997 [5]. The aim of this article is to describe the case of a patient who received such treatment.

\section{CASE DESCRIPTION}

A 56-year-old man reported to a sleep disorder outpatient clinic because of sudden movement disorders during sleep, usually in the form of punching and kicking. His family told him that it appeared as he was fighting with somebody. The episodes were often accompanied by screaming and insulting language. They were of short duration, usually lasted several seconds. The patient was
CEL

Parasomnie są zaburzeniami ruchowymi występującymi w czasie snu nocnego lub w okresach przejścia między snem a czuwaniem. Ze względu na stadium snu, w którym występują, dzieli się je na parasomnie związane ze snem REM, czyli z szybkimi ruchami gałek ocznych (rapid eye movement sleep), lub związane ze snem NREM (non-rapid eye movement sleep) [1]. Właściwe rozpoznanie rodzaju parasomnii implikuje wdrożenie odpowiedniego leczenia. W przypadku parasomnii związanych ze snem REM powodem zgłoszenia się do lekarza są często zaburzenia zachowania w czasie snu REM (REM sleep behavior sleep disorder - RBD). Zaburzenie to charakteryzuje się złożonymi, często gwałtownymi ruchami ciała i/lub wokalizacjami ściśle związanymi z treścią marzenia sennego [2]. Marzenia senne wywołujące RBD są często bardzo żywe, pełne negatywnych emocji, o treściach związanych z ucieczką, pogonią, walką, innymi zagrożeniami, co manifestuje się gwałtownymi ruchami kończyn o typie boksowania, szczypania, drapania, kopania. Epizody takie mogą prowadzić do uszkodzeń ciała osoby chorej lub osoby śpiącej z nią w jednym łóżku. Najczęściej są to urazy czy złamania kości kończyn, ale również poważniejsze urazy głowy związane $\mathrm{z}$ upadkiem $\mathrm{z}$ łóżka $[3,4]$. RBD może objawiać się również towarzyszącymi ruchom lub izolowanymi głośnymi wokalizacjami w postaci krzyku, pojedynczych słów, złożonych wypowiedzi. Cechą powodującą zawstydzenie pacjentów jest wykrzykiwanie słów wulgarnych podczas epizodów RBD, szczególnie u osób, które nie stosują wulgaryzmów w życiu codziennym. Objawy RBD mogą być początkowo niezauważone, ze względu na mniejsze ich nasilenie. Objawy ruchowe mogą ograniczać się do ruchów palców, rąk i odzwierciedlać marzenie senne związane np. z często wykonywaną pracą (gra na pianinie, szydełkowanie). Ze względu na związek RBD ze snem REM zaburzenie występuje głównie w drugiej połowie nocy, gdy okresy snu REM są częstsze i dłuższe. Liczba epizodów RBD jest różna, od kilku w ciągu roku do kilku w ciągu każdej nocy.

Najczęściej stosowanym lekiem zmniejszającym objawy RBD jest klonazepam. Lek ten jest jednak obarczony szeregiem działań niepożądanych, zwłaszcza w grupie pacjentów starszych. W 1997 r. po raz pierwszy opisano korzystne działanie melatoniny w terapii RBD [5]. Celem artykułu jest opisanie przypadku pacjenta, który otrzymał takie leczenie.

\section{OPIS PRZYPADKU}

Mężczyzna, 56 lat, zgłosił się do poradni leczenia zaburzeń snu z powodu występowania gwałtownych zaburzeń ruchowych podczas snu, najczęściej w postaci uderzania kończynami górnymi, kopania nogami. Członkowie rodziny opisywali, że chory sprawia wrażenie, jakby z kimś walczył. Epizodom często towarzyszyły krzyk i obraźliwe wypowiedzi. Epizody trwały krótko, najczęściej kilkanaście 
often woken up by his wife during the episodes and then he told the content of his dreams in which he participated in a brawl or robbery, or was running away from someone. As reported by his wife, the first episodes appeared 2 years before the visit to the clinic. Initially, the movement episodes occurred rarely, every 3-4 months. However, after a year, the number of episodes increased and they were occurring almost every night. The sleep disorders became so dangerous that the couple slept in separate beds. The patient's decision to seek advice in the sleep disorder outpatient clinic was accelerated by the fact that during one of the episodes he hit the wall and broke his right hand wrist bone. The history of other diseases shows that the patient was suffering from hypertension and had been taking an antihypertensive from the ACE inhibitor group in a fixed dose for 9 years, with good control of blood pressure. He had never had a head injury; as a teenager, he underwent surgery for appendicitis. In his youth, he smoke cigarettes; he had not been smoking for more than 20 years; he drank alcohol occasionally. His family members did not suffer from movement disorders during sleep, but his father suffering from Alzheimer's disease experienced circadian sleep and wake rhythm disorder.

Before reporting to a sleep disorder outpatient clinic, the patient consulted an internist and neurologist. Endocrine and metabolic diseases were excluded. Neurological examination revealed normal state. Due to the fact that a family member suffered from Alzheimer's disease and the possibility of the occurrence of RBD symptoms in dementia syndromes, a cognitive function screening test (Minimental State Examination, MMSE) was performed, in which the patient scored 29 points, which is recognised as normal. MRI of the brain revealed a few small angiogenic cortical foci in both hemispheres of the brain.

On the basis of the characteristic clinical image, the initial diagnosis of idiopathic REM sleep behaviour disorders was given, which was then confirmed by video-polysomnography (v-PSG).

Video-polysomnography was performed in line with recommendations of the American Academy of Sleep Medicine (AASM). During the test, fragments of muscle atonia were recorded in all REM sleep periods. In addition, movement episodes were recorded twice during REM sleep: the first one, lasting a few seconds, involved arm flailing and murmuring, and the second, longer one, lasting approximately 1 minute, involving punching and pulling the pillow, and shouting. No other major sleep disorders, including breathing disorders during sleep, were identified during the v-PSG test.

Having discussed therapeutic possibilities with the patient, a decision was made to introduce melatonin in the initial dose of $3 \mathrm{mg}$, to be taken about one hour before bedtime. After 2 weeks, the dose of melatonin was increased to $5 \mathrm{mg}$ to increase drug efficacy. Furthermore, the patient was advised to change his bed to a wide and sekund. Pacjent często był budzony przez żonę w czasie trwania epizodu i wówczas opowiadał treść marzenia sennego, w którym był uczestnikiem bójki, napadu lub przed kimś uciekał. Według relacji żony zachorowanie pacjenta nastąpiło ok. 2 lata przed wizytą w poradni. Początkowo epizody ruchowe występowały rzadko, co 3-4 miesiące, ale po roku nastąpiło zwiększenie liczby epizodów i pojawiały się one niemal każdej nocy. Zaburzenia w czasie snu stały się na tyle niebezpieczne, że małżonkowie sypiali w oddzielnych łóżkach. Zgłoszenie się pacjenta do poradni zaburzeń snu przyspieszył fakt, że podczas jednego z epizodów, na skutek uderzenia w ścianę, doszło do złamania kości nadgarstka prawej ręki. $Z$ wywiadu dotyczącego innych chorób wiadomo, że pacjent chorował na nadciśnienie tętnicze, od 9 lat stosował lek przeciwnadciśnieniowy z grupy inhibitorów konwertazy angiotensyny w stałej dawce, z dobrą kontrolą ciśnienia tętniczego; nigdy nie doznał urazu głowy, jako nastolatek był operowany z powodu zapalenia wyrostka robaczkowego. W młodości palił papierosy, od ponad 20 lat nie palił, alkohol spożywał okazjonalnie. $\mathrm{W}$ rodzinie nie występowały zaburzenia ruchowe w czasie snu, ale ojciec pacjenta, cierpiący na chorobę Alzheimera, miał zaburzony rytm okołodobowy snu i czuwania.

Przed zgłoszeniem się do poradni leczenia zaburzeń snu pacjent był konsultowany przez internistę i neurologa. Wykluczono choroby metaboliczne i endokrynologiczne. W badaniu neurologicznym stwierdzono stan prawidłowy. Ze względu na występowanie choroby Alzheimera w wywiadzie rodzinnym oraz możliwość występowania objawów RBD w zespołach otępiennych przeprowadzono przesiewowe badanie funkcji poznawczych (Minimental State Examination - MMSE), w którym to teście pacjent uzyskał wynik 29 pkt, uznany za prawidłowy. Badanie rezonansu magnetycznego mózgu uwidoczniło kilka drobnych korowych ognisk naczyniopochodnych w obu półkulach mózgu.

$\mathrm{Na}$ podstawie charakterystycznego obrazu klinicznego ustalono wstępne rozpoznanie idiopatycznej postaci zaburzeń zachowania w czasie snu REM, następnie potwierdzone badaniem polisomnograficznym $\mathrm{z}$ rejestracją wideo (v-PSG).

Badanie v-PSG wykonano zgodnie z zaleceniami Amerykańskiej Akademii Medycyny Snu (AASM). W czasie badania we wszystkich okresach snu REM rejestrowano fragmenty zaburzeń atonii mięśniowej. Ponadto dwukrotnie $\mathrm{w}$ czasie snu REM zarejestrowano epizody ruchowe: pierwszy z nich kilkusekundowy, w postaci wymachiwania rękami i pomrukiwania oraz drugi, dłuższy, trwający ok. 1 minuty w postaci uderzania i szarpania poduszki, pokrzykiwania. W badaniu v-PSG nie stwierdzono innych istotnych zaburzeń snu, w tym zaburzeń oddychania.

Po przedyskutowaniu z pacjentem możliwości terapeutycznych zdecydowano o wdrożeniu melatoniny początkowo $\mathrm{w}$ dawce $3 \mathrm{mg}$, podawanej na około godzinę przed snem. Po 2 tygodniach dawkę melatoniny zwiększono do $5 \mathrm{mg} \mathrm{w}$ celu zwiększenia skuteczności działania leku. Dodatkowo zalecono pacjentowi zmianę łóżka na 
lower one, and to move the bed away from the walls to minimise the risk of injury. A check-up was scheduled to after 8 weeks. The patient's wife observed a significant reduction in the number of RBD episodes. During treatment with melatonin in the dose of $5 \mathrm{mg}$, RBD episodes occurred several times a month and were clearly less severe. The patient also reported improved quality of sleep at night - its continuity was improved, the number of arousals was decreased and the number of dreams of unpleasant content was reduced. Medication was well tolerated by the patient. He did not report any adverse reactions. Due to good efficacy and tolerance of melatonin, this treatment was continued. The patient also remained under supervision of a neurologist due to a higher risk of a neurodegenerative disease.

\section{COMMENT}

This article presents the case of a patient with REM sleep behaviour disorder, who took melatonin with the desired effect and good tolerance.

$\mathrm{RBD}$ is a parasomnia with the prevalence of $0.38-0.5 \%$ in the general population, most often in men older than 50 years old [6]. In persons aged 70 and older the prevalence of RBD increases even up to $2 \%$ [7]. It may occur as an idiopathic disorder (iRBD), but most often it is a symptom of other neurodegenerative diseases from the group of alpha-synucleinopathies, such as Parkinson's disease, multiple system atrophy and dementia with Lewy bodies $[8,9]$. An idiopathic form of RBD in approximately 80 $90 \%$ of cases is a prodromal symptom that appears even 10-20 years before the onset of these diseases [10, 11]. For this reason, patients with RBD require systematic examination by a neurologist, preferably every 6-12 months to identify the first symptoms of a neurodegenerative disease and to introduce appropriate treatment at early stages of the disease. Co-occurrence of RBD in other neurodegenerative diseases, such as Alzheimer's disease, progressive supranuclear palsy and frontotemporal lobar degeneration, was reported much less frequently.

RBD may also occur in younger persons, for example those suffering from type 1 narcolepsy (narcolepsy with cataplexy) [12], as a symptom of spinocerebellar angle tumour and as an adverse reaction of certain drugs, particularly antidepressants [13]. The mechanism of muscle atonia disorders and RBD during REM sleep most likely involves the disruption of the inhibitory action of basal nuclei on spinal cord and brainstem motoneurons [8].

The diagnosis of RBD is based mainly on the medical history of the patient and information obtained from relatives of the patient. Characteristic features of episodes, such as suddenness of movements, vocalizations, cyclic occurrence of episodes during the night (in line with the cyclically occurring REM sleep periods), movements reflecting the content of dreams, and szerokie i niższe, oddalenie łóżka od ścian w celu zminimalizowania ryzyka urazu. Wizytę kontrolną zaplanowano po 8 tygodniach. Żona pacjenta zaobserwowała znaczne zmniejszenie liczby epizodów RBD. W trakcie leczenia melatoniną $\mathrm{w}$ dawce $5 \mathrm{mg}$ epizody RBD występowały kilka razy w miesiącu i były wyraźnie łagodniejsze. Pacjent również relacjonował poprawę jakości snu nocnego w postaci poprawy jego ciągłości, mniejszej liczby wybudzeń oraz redukcji liczby marzeń sennych o nieprzyjemnej treści. Chory dobrze tolerował lek, nie zgłaszał działań niepożądanych. Ze względu na dobrą skuteczność i tolerancję melatoniny leczenie to zostało utrzymane. Pacjent pozostał również pod obserwacją lekarza neurologa $\mathrm{z}$ powodu podwyższonego ryzyka zachorowania na chorobę neurozwyrodnieniową.

\section{KOMENTARZ}

W pracy przedstawiono przypadek pacjenta $\mathrm{z}$ zaburzeniami zachowania w czasie snu REM, u którego zastosowano melatoninę z pożądanym skutkiem i dobrą tolerancją.

$\mathrm{RBD}$ jest parasomnią występującą z częstością 0,38-0,5\% w populacji ogólnej, najczęściej dotyczącą mężczyzn po 50. roku życia [6]. Po 70. roku życia częstość występowania RBD zwiększa się nawet do 2\% [7]. Może występować jako zaburzenie idiopatyczne (iRBD), ale najczęściej jest objawem innych chorób neurozwyrodnieniowych z grupy alfa-synukleinopatii, np. choroby Parkinsona, zaniku wieloukładowego oraz otępienia z ciałami Lewy'ego $[8,9]$. Postać idiopatyczna RBD w ok. 80-90\% przypadków jest objawem prodromalnym, wyprzedzającym zachorowanie na wymienione choroby nawet o 10-20 lat $[10,11]$. Z tego względu pacjenci z RBD wymagają systematycznej oceny lekarza neurologa, najlepiej co 6-12 miesięcy w celu rozpoznania pierwszych objawów choroby neurozwyrodnieniowej i wdrożenia odpowiedniego leczenia we wczesnym stadium choroby. Znacznie rzadziej opisywano współwystępowanie RBD w innych chorobach neurozwyrodnieniowych: chorobie Alzheimera, postępującym porażeniu nadjądrowym i zwyrodnieniu czołowo-skroniowym.

RBD może również występować u młodszych osób, np. chorujących na narkolepsję typu 1 (narkolepsję z katapleksją) [12], jako objaw guza kąta rdzeniowo-móżdżkowego oraz jako działanie niepożądane niektórych leków, zwłaszcza przeciwdepresyjnych [13]. Mechanizm powstawania zaburzeń atonii mięśniowej i RBD w czasie snu REM najprawdopodobniej polega na zakłóceniu hamującego działania jąder podstawy mózgu na motoneurony rdzenia kręgowego i pnia mózgu [8].

Rozpoznanie RBD opiera się przede wszystkim na wywiadzie od chorego oraz osób mu bliskich. Charakterystyczne cechy epizodów, tj. gwałtowność ruchów, wokalizacje, cykliczne występowanie epizodów w ciągu nocy (zgodnie z cyklicznie występującymi okresami snu REM), czynności ruchowe ilustrujące treść marzenia sennego, często pamięć 
frequently the memory of the dream when the patient wakes up, make it possible to give the initial diagnosis of RBD. In medical practice, screening scales for RBD are also useful [14-16]. RBD1Q is a short screening tool with only one question: "Have you ever been told, or suspected yourself, that you seem to 'act out your dreams' while asleep (for example, punching, flailing your arms in the air, making running movements)?". The advantage of the scale is a high sensitivity (95\%) and specificity (87\%) in the study involving polysomnography [16]. Mayo Sleep Questionnaire, containing the question: "Have you ever seen the patient appear to 'act out his/her dreams' while sleeping (punched or flailed arms in the air, shouted or screamed?", addressed to caregivers, is a similar screening tool. If the answer is 'yes', additional 5 questions are asked to define symptoms [15]. According to the third edition of the International Classification of Sleep Disorders (ICSD-3), the diagnosis of RBD, except for the occurrence of characteristic symptoms, requires polysomnographic study, documenting the episode of RBD and/or recording of REM sleep periods without muscle atonia (REM sleep without atonia, RWA) [17]. In practice, however, the availability of such testing is significantly limited due to its high cost and a small number of centres offering the performance of v-PSG testing in neurological and mental disorders. In the majority of cases, characteristic clinical features of the episodes, more often supplemented by videos recorded by family members of the patient, are sufficient to diagnose RBD. In cases of doubt, for example when the episodes are not typical, are difficult to distinguish from sleep-related epileptic seizures, or there are no witnesses who could describe the episodes, as well as when co-occurrence of other sleep disorders, such as breathing disorders during sleep, is suspected, video-polysomnography is necessary. According to the recommendations of the American Academy of Sleep Medicine, in patients with suspected RBD, in addition to EMG of the mental and both anterior tibialis muscles, additional EMG of both flexor digitorum superficialis muscles should be used [18]. An increased number of EMG channels significantly, by approximately $60 \%$, increases the indices of EMG phase activity seen during the RBD episode compared to EMG activity recorded only from chin muscles [19]. V-PSG often makes it possible to record a clinical episode of RBD. If a clinical episode does not occur, EMG presents REM without atonia (RWA), defined as persistent tonic muscle activity in chin EMG during REM sleep (an increase in muscle tone for more than $50 \%$ of 30 -second fragments of sleep assessed during PSG testing) and/or transient phasic muscle activity in the chin or limb EMG (muscle activity discharges lasting 0.1-0.5 s with an amplitude 2-4 times higher marzenia sennego po obudzeniu $\mathrm{z}$ epizodu, pozwalają na postawienie wstępnego rozpoznania RBD. W praktyce lekarskiej przydatne są również przesiewowe skale dotyczące RBD [14-16]. RBD1Q screening jest krótką skalą, zawierającą jedno pytanie: „Czy kiedykolwiek mówiono Panu/ Pani lub podejrzewa Pan/Pani, że podczas snu odtwarza treść marzenia sennego (np. uderza pięściami, wymachuje rękami, wykonuje ruchy przypominające bieganie)?". Zaletą skali jest wysoka czułość (95\%) i specyficzność (87\%) w badaniu przeprowadzonym z polisomnografią [16]. Podobnym narzędziem przesiewowym jest Mayo Sleep Questionaire, zawierający jedno pytanie skierowane do opiekunów pacjentów: „Czy kiedykolwiek zauważył/a Pan/Pani, że pacjent podczas snu zachowuje się, jakby odtwarzał treść marzenia sennego (bił pięściami lub wymachiwał rękami lub krzyczał)?". W przypadku pozytywnej odpowiedzi następuje dodatkowych 5 pytań precyzujących objawy [15]. Według trzeciej edycji Międzynarodowej Klasyfikacji Zaburzeń Snu (ICSD-3) rozpoznanie RBD, poza obecnością charakterystycznych objawów, wymaga wykonania badania polisomnograficznego, dokumentującego epizod RBD i/lub rejestrację okresów snu REM bez atonii mięśniowej (REM sleep without atonia - RWA) [17]. W praktyce jednak dostępność do takiego badania jest znacznie ograniczona, ze względu na jego wysoki koszt i niewielką liczbę ośrodków oferujących wykonanie badania v-PSG w chorobach neurologicznych i zaburzeniach psychicznych. W większości przypadków charakterystyczne cechy kliniczne epizodów, uzupełniane coraz częściej przez materiał filmowy nagrywany przez członków rodziny pacjenta, są wystarczające, aby rozpoznać RBD. W przypadkach budzących wątpliwości, np. gdy epizody są nietypowe, trudne do odróżnienia od napadów padaczkowych związanych ze snem lub brakuje świadków mogących opisać epizody, a także przy podejrzeniu współwystępowania innych zaburzeń snu, np. zaburzeń oddychania w czasie snu, wykonanie badania polisomnograficznego z rejestracją wideo jest konieczne. Według zaleceń Amerykańskiej Akademii Medycyny Snu u pacjentów z podejrzeniem RBD oprócz odprowadzeń EMG znad mięśni podbródkowych oraz mięśni piszczelowych przednich lewego i prawego powinny być stosowane dodatkowe odprowadzenia EMG znad mięśni zginaczy powierzchownych palców [18]. Większa liczba odprowadzeń EMG wyraźnie, bo o ok. 60\% zwiększa wskaźniki fazowej czynności EMG widocznej podczas epizodu RBD w stosunku do aktywności EMG rejestrowanej jedynie z mięśni podbródkowych [19]. Badanie v-PSG często pozwala na zarejestrowanie epizodu klinicznego RBD. W przypadku braku epizodu klinicznego w zapisie EMG rejestruje się zaburzenia atonii mięśniowej w okresach snu REM (RWA), definiowane jako przetrwała toniczna aktywność mięśniowa w EMG znad mięśni podbródkowych w czasie snu REM (wzrost napięcia mięśniowego przez ponad $50 \%$ trzydziestosekundowych fragmentów snu ocenianych w badaniu PSG) oraz/lub nadmierna przemijająca fazowa aktywność mięśni w EMG znad mięśni 
than the baseline activity) [18]. The most important management in all RBD cases is to ensure the safety of the patient and their bed partner [20]. The patient should sleep alone. The bed should be wide, low and moved away from the walls, furniture and other equipment. In mild and rarely occurring RBD episodes, the rules to ensure protection against injuries are sufficient practice. In severe cases, for example if the episodes occur repeatedly during the night, are so violent that they may result in injuries or make the patient embarrassed and in consequence cause other emotional disorders, pharmacotherapy is advisable.

Until recently, clonazepam in the dose of $0.5-2 \mathrm{mg}$ before bedtime was recommended as a drug of the first choice. However, there are many adverse reactions and the risk of addiction associated with this drug. Particularly adverse effects in the elderly include daytime sleepiness, increased risk of falls, cognitive dysfunction and intensification of breathing disorders during sleep [21]. For this reason, clonazepam should not be used chronically. A safer way to use clonazepam is to take it on a short-term basis, for example during the journey or health resorts stays, when the patient has to sleep in the same room with other people. A number of recent observational studies and less numerous, small, placebo-controlled studies showed moderate efficacy of exogenous melatonin in the treatment of RBD [22-24]. Concerning very good tolerance of melatonin compared to clonazepam, melatonin becomes a drug that is more frequently selected to be chronically used in RBD. In RBD, as in the treatment of insomnia, patients who are more than 55 years old [25] should take melatonin about one hour before bedtime, in the initial dose of 2-3 mg; if no effect is observed, the dose can be increased up to $15 \mathrm{mg}$, while the optimum tolerance with good efficacy is $3-5 \mathrm{mg}$ [20].

Due to the potentially beneficial effects in RBD, attempts were also made to treat this disorder with dopamine agonists (pramipexole, ropinirole) [26] and acetylcholinesterase inhibitors (donepezil, rivastigmine) [27]. The efficacy of drugs of such different mechanism of action in RBD may result from a complex pathogenesis of the disorder, indicating the participation of serotonergic, noradrenergic, hypocretin, acetylcholine, GABAergic and dopaminergic neurons [28]. The results of the attempts to treat this disorder using the aforementioned drugs are, however, ambiguous, many studies do not show their beneficial effect $[29,30]$. Currently, they are treated as drugs of the third choice and are recommended mainly to patients with Parkinsonian syndromes (dopamine agonists) or dementia syndromes (acetylcholinesterase inhibitors). podbródkowych lub mięśni kończyn (wyładowania aktywności mięśniowej trwające 0,1-0,5 s o amplitudzie 2-4-krotnie wyższej od aktywności wyjściowej) [18]. Najważniejszym postępowaniem we wszystkich przypadkach RBD jest zapewnienie bezpieczeństwa pacjentowi oraz osobie z nim śpiącej w jednym łóżku [20]. Pacjent powinien sypiać sam; łóżko do spania powinno być szerokie, niskie, odsunięte od ścian, mebli i innych sprzętów, w które mógłby uderzyć się pacjent. W łagodnych lub rzadko występujących epizodach RBD zasady zapewnienia bezpieczeństwa przed urazami są wystarczającym postępowaniem. W przypadkach ciężkich, np. gdy epizody występują wielokrotnie w ciągu nocy, są na tyle gwałtowne, że zagrażają uszkodzeniem ciała lub powodują u pacjenta poczucie wstydu i w konsekwencji inne zaburzenia emocjonalne, wskazane jest wdrożenie farmakoterapii.

Do niedawna jako lek pierwszego wyboru w RBD zalecano klonazepam w dawkach 0,5-2 mg przed snem. Jednakże lek ten obarczony jest szeregiem działań niepożądanych oraz ryzykiem rozwoju uzależnienia. Do szczególnie niekorzystnych działań u osób starszych należą: senność w ciągu dnia, zwiększone ryzyko upadków, zaburzenia funkcji poznawczych, nasilenie zaburzeń oddychania $\mathrm{w}$ czasie snu [21]. Z tego względu klonazepam nie powinien być stosowany przewlekle. Bezpieczniejszym sposobem stosowania klonazepamu jest podawanie go jako środka doraźnego, np. w czasie podróży, turnusów uzdrowiskowych, gdy pacjent jest zmuszony spać $\mathrm{w}$ jednym pomieszczeniu $\mathrm{z}$ innymi osobami. Szereg ostatnich badań obserwacyjnych oraz mniej licznych, małych badań kontrolowanych placebo wskazało na umiarkowaną skuteczność egzogennej melatoniny w leczeniu RBD [22-24]. Biorąc pod uwagę bardzo dobrą tolerancję melatoniny w porównaniu z klonazepamem, staje się ona coraz częściej wybieranym lekiem do stosowania przewlekłego w RBD. W RBD, podobnie jak w leczeniu bezsenności po 55. roku życia [25], melatoninę należy przyjmować około godzinę przed snem, $\mathrm{w}$ dawce początkowej 2-3 mg, przy braku efektu dawkę można zwiększyć aż do $15 \mathrm{mg}$, przy czym optymalna tolerancja przy dobrej skuteczności to 3-5 mg [20].

Ze względu na potencjalnie korzystne działanie w RBD prowadzono również próby leczenia tego zaburzenia agonistami dopaminy (pramipeksolem, ropinirolem) [26] oraz inhibitorami acetylocholinoesterazy (donepezilem, rywastygminą) [27]. Skuteczność leków o tak różnym mechanizmie działania w RBD może wynikać ze złożonej patogenezy zaburzenia, wskazującej na udział neuronów serotoninergicznych, noradrenergicznych, hipokretynowych, acetylocholinowych, gabaergicznych i dopaminergicznych [28]. Wyniki prób leczenia wymienionymi lekami są jednak niejednoznaczne, $w$ wielu badaniach nie wykazano ich korzystnego efektu $[29,30]$. Są one obecnie traktowane jako leki trzeciego wyboru i zalecane głównie pacjentom $\mathrm{z}$ zespołami parkinsonowskimi (agoniści dopaminy) lub zespołami otępiennymi (inhibitory acetylocholinoesterazy). 


\section{CONCLUSIONS}

1. REM sleep behaviour disorder is a sleep disorder with characteristic clinical features, sometimes requiring to be verified by video-polysomnography.

2. Patients with an idiopathic form of RBD should remain under permanent supervision of a neurologist due to an increased risk of a neurodegenerative disease.

3. RBD treatment should mainly involve ensuring safety of the patient. Clonazepam and melatonin are drugs recommended in the treatment of $\mathrm{RBD}$.

\section{WNIOSKI}

1. Zaburzenia zachowania $\mathrm{w}$ czasie snu REM są zaburzeniem snu o charakterystycznych cechach klinicznych, niekiedy wymagającym zweryfikowania badaniem polisomnograficznym $\mathrm{z}$ rejestracją wideo.

2. Pacjenci z idiopatyczną postacią RBD powinni pozostawać pod stałą kontrolą neurologiczną ze względu na zwiększone ryzyko zachorowania na choroby neurozwyrodnieniowe.

3. Leczenie RBD powinno polegać przede wszystkim na zapewnieniu bezpieczeństwa pacjentowi. Lekami zalecanymi w leczeniu RBD są klonazepam i melatonina.

\section{Conflict of interest/Konflikt interesu}

Absent./Nie występuje.

Financial support/Finansowanie

Absent./Nie występuje.

\section{References/Piśmiennicłwo}

1. International Classification of Sleep Disorders $3^{\text {rd }}$ ed. Westchester, IL: American Academy of Sleep Medicine; 2014.

2. Schenck CH, Mahowald MW. REM sleep behavior disorder: clinical, developmental and neuroscience perspectives 16 years after its formal identification in SLEEP. Sleep 2002; 25: 120-138.

3. McCarter SJ, St Louis EK, Boswell CL, Dueffert LG, Slocumb N, Boeve BF, et al. Factors associated with injury in REM sleep behavior disorder. Sleep Med 2014; 15: 1332-1338.

4. Chiu HF, Wing YK, Lam LC, Li SW, Lum CM, Leung T, et al. Sleep-related injury in the elderly - an epidemiologica study in Honk-Kong. Sleep 2000; 23: 513-517.

5. Kunz D, Bes F. Melatonin effects in a patient with severe REM sleep behavior disorder: case report and theoretical considerations. Neuropsychobiology 1997; 36: 211-214.

6. Ohayon MM, Schenck CH. Violent behavior during sleep: prevalence, comorbidity and consequences. Sleep Med 2010; 11: 941-946.

7. Boeve BF, Molano JR, Ferman TJ, Smith GE, Lin SC, Bieniek K, et al. Validation of the Mayo Sleep Questionnaire to screen for REM sleep behavior disorder in an aging and dementia cohort. Sleep Med 2011; 12: $445-453$.

8. Boeve BF. REM sleep behavior disorder: Updated review of the core features, the REM sleep behavior disorderneurodegenerative disease association, evolving concepts, controversies, and future directions. Ann N Y Acad Sci 2010; 1184: 15-54.

9. Iranzo A, Santamaria J, Tolosa E. The clinical and pathophysiological relevance of REM sleep behavior disorder in neurodegenerative diseases. Sleep Med Rev 2009; 13: 385-401.

10. Schenck CH, Boeve BF, Mahowald MW. Delayed emergence of a parkinsonian disorder or dementia in $81 \%$ of older men initially diagnosed with idiopathic rapid eye movement sleep behavior disorder: a 16-year update on a previously reported series. Sleep Med 2013; 14: 744-748.

11. Iranzo A, Fernández-Arcos A, Tolosa E, Serradell M, Molinuevo JL, Valldeoriola F, et al. Neurodegenerative disorder risk in idiopathic REM sleep behavior disorder: study in 174 patients. PLoS One 2014; 9: e89741.

12. Dauvilliers Y, Jennum P, Plazzi G. Rapid eye movement sleep behavior disorder and rapid eye movement sleep without atonia in narcolepsy. Sleep Med 2013; 14: 775-781.

13. Lee K, Baron K, Soca R, Attarian H. The prevalence and characteristics of REM sleep without atonia (RSWA) in patients taking antidepressants. J Clin Sleep Med 2016; 12: 351-355.

14. Stiasny-Kolster K, Mayer G, Schäfer S, Möller JC, Heinzel-Gutenbrunner M, Oertel WH. The REM sleep behavior disorder screening questionnaire - a new diagnostic instrument. Mov Disord 2007; 22: 2386-2393.

15. Boeve BF, Molano JR, Ferman TJ, Lin SC, Bieniek K, Tippmann-Peikert M, et al. Validation of the Mayo Sleep Questionnaire to screen for REM sleep behavior disorder in a community-based sample. J Clin Sleep Med 2013; 9: 475-480. 
16. Postuma RB, Arnulf I, Hogl B. A single-question screen for rapid eye movement sleep behavior disorder: a multicenter validation study. Mov Disord 2012; 27: 913-916.

17. American Academy of Sleep Medicine. International Classification of Sleep Disorders, $3^{\text {rd }}$ edition, 2014.

18. American Academy of Sleep Medicine. Manual for the scoring of sleep and associated events: rules, terminology and technical specifications. Version 2.3 (April 2016).

19. Iranzo A, Frauscher B, Santos H, Gschliesser V, Ratti L, Falkenstetter T, et al. Usefulness of the SINBAR EMG montage to detect the motor and vocal manifestations occurring in REM sleep behavior disorder. Sleep Med 2011; 12: 284-288.

20. Jung Y, St Louis E. Treatment of REM sleep behavior disorder. Curr Treat Options Neurol 2016; 18: 50.

21. Aurora RN, Zak RS, Maganti RK, Auerbach SH, Casey KR, Chowdhuri S, et al. Best practice guide for the treatment of REM sleep behavior disorder (RBD). J Clin Sleep Med 2010; 6: 85-95.

22. Kunz D, Bes F. Melatonin as a therapy in REM sleep behavior disorder patients: an open-labeled pilot study on the possible influence of melatonin on REM-sleep regulation. Mov Disord 1999; 14: 507-511.

23. Kunz D, Mahlberg R. A two-part, double-blind, placebo-controlled trial of exogenous melatonin in REM sleep behaviour disorder. J Sleep Res 2010; 19: 591-596.

24. McCarter SJ, Boswell CL, St Louis EK, Dueffert LG, Slocumb N, Boeve BF, et al. Treatment outcomes in REM sleep behavior disorder. Sleep Med 2013; 14: 237-242.

25. Wilson SJ, Nutt DJ, Alford C, Argyropoulos SV, Baldwin DS, Bateson AN, et al. British Association for Psychopharmacology consensus statement on evidence-based treatment of insomnia, parasomnias and circadian rhythm disorders. J Psychopharmacol 2010; 24: 1577-1601.

26. Fantini ML, Gagnon JF, Filipini D, Montplaisir J. The effects of pramipexole in REM sleep behavior disorder. Neurology 2003; 61: 1418-1420.

27. Di Giacopo R, Fasano A, Quaranta D, Della Marca G, Bove F, Bentivoglio AR. Rivastigmine as alternative treatment for refractory REM behavior disorder in Parkinson's disease. Mov Disord 2012; 27: 559-561.

28. Aurora RN, Zak R, Maganti R, Auerbach SH, Casey KR, Chowdhuri S, et al. Best practice guide for the treatment of REM sleep behavior disorder (RBD). J Clin Sleep Med 2010; 6: 85-95.

29. Kumru H, Iranzo A, Carrasco E, Valldeoriola F, Marti MJ, Santamaria J, et al. Lack of effects of pramipexole on REM sleep behavior disorder in Parkinson disease. Sleep 2008; 31: 1418-1421.

30. Carlander B, Touchon J, Ondze B, Billiard M. REM sleep behavior disorder induced by cholinergic treatment in Alzheimer's disease. J Sleep Res 1996; 5 Suppl 1: 28. 
